\title{
Natural and Artificial Methods of Heat Resources Regeneration in Underground Thermal Energy Storages with Borehole Heat Exchangers
}

\author{
Tomasz Śliwa ${ }^{1, *}$ and Marc A. Rosen ${ }^{2}$ \\ ${ }^{1}$ AGH University of Science and Technology, Cracow, Poland, Drilling, Oil and Gas Faculty, Drilling \\ and Geoengineering Department, al. Mickiewicza 30, 30-059 Cracow, Poland \\ ${ }^{2}$ Faculty of Engineering and Applied Science, University of Ontario Institute of Technology, Oshawa, \\ Ontario, L1H 7K4, Canada \\ E-Mails: sliwa@agh.edu.pl; marc.rosen@uoit.ca \\ * Author to whom correspondence should be addressed; Tel.: +48-12-617-37-84; Fax: +48-12-617-22- \\ 06
}

Received: 20 October 2014 / Accepted: 2 November 2014 / Published: 3 November 2014

\begin{abstract}
The concept of borehole heat exchanger (BHE) field exploitation is described, along with problems regarding the sustainability of heat resources in rock masses. A BHE field sometimes has problems with the stability of the heat carrier temperature during longterm exploitation. The main reason for this is an insufficient heat stream with which to transfer heat by conduction in rock. Based on experiences at the Geoenergetics Laboratory (Drilling, Oil and Gas Faculty, AGH University of Science and Technology), possibilities for the regeneration of heat in rock masses are described.
\end{abstract}

Keywords: Borehole heat exchanger, geoenergetics, heat pump, underground thermal energy storage keyword.

\section{Introduction}

Borehole thermal energy storages (BTESs) are increasing in interest and implementation, especially with systems for heating and/or cooling. The use of traditional fossil fuels only to keep buildings at 
approximately $20^{\circ} \mathrm{C}$ is wasteful, as there is a significant mismatch in the qualities of energy supply and demand. That is, fossil fuels are too valuable for use in heating/cooling. They can be used in more sophisticated systems and to meet higher quality energy needs. The heat pump is a technology that is more efficiency for heating and cooling, in part because it matches the quality of the energy demand and supply better.

One technology for helping to meet the building heat demand is the borehole heat exchanger (BHE). This technology is often advantageous in most locations, and is independent of geological conditions. Shallow holes (to depths of about $200 \mathrm{~m}$ ) are used for heat/cool storage and extraction. Deeper BHEs are generally only for used heating (Sapinska-Sliwa et al. 2015). Typical constructions for BHEs are presented in fig. 1. The most popular construction is the U-tube design (a), while the least common is the coaxial type (c). Generally the best heat transfer condition is observed for the coaxial system, but this depends on many factors, including good installation execution (workmanship). Examples of other situations where U-tubes construction are advantageous are presented by Sapinska-Sliwa et al. (2014).

Figure 1. BHE constructions: a) single U-tube, b) double U-tube, c) coaxial (Gonet et al. 2011). Legend: 1 - borehole wall, 2 - grout, 3 - interior of U-tube, 4 - U-tube wall, 5 - annulus space, 6 - inner column (pipe), 7 - interior of inner column (pipe).
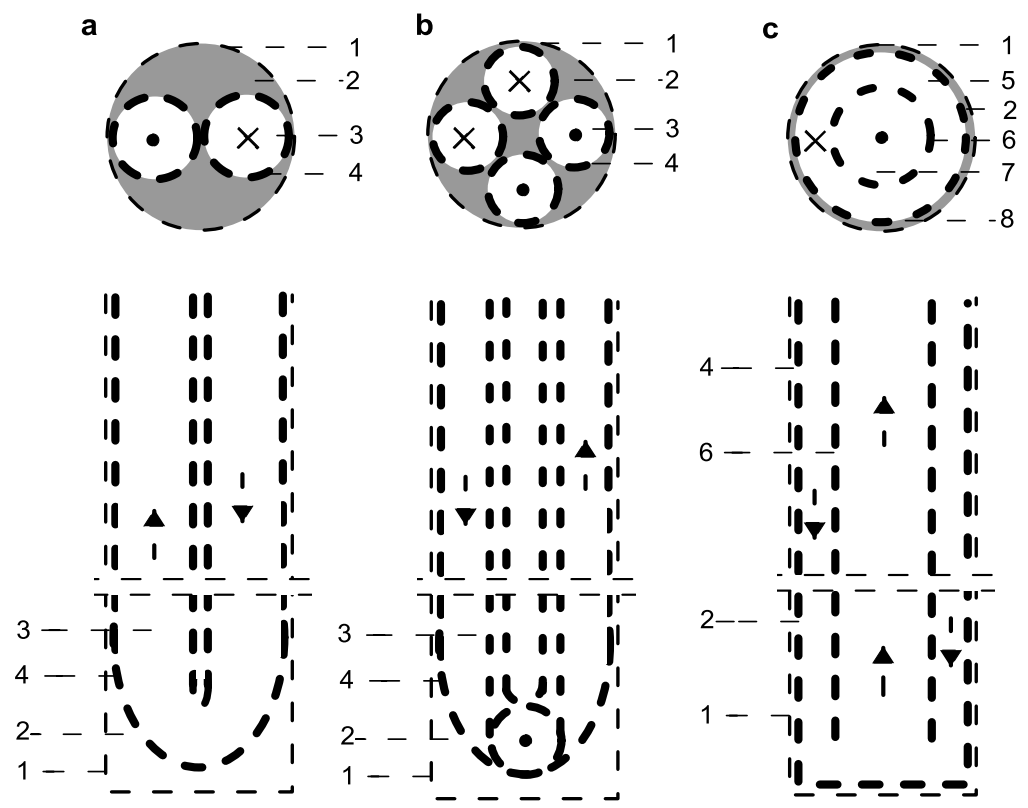

Borehole heat exchanger fields are in operation for heat extraction and cold extraction; some reversing systems exist that provide heat and cool extraction. When the number of BHEs is low (one or few) there usually is no problem with heat carrier temperature during the long period of exploitation (often years). When number of BHE is high (tens or more) there is the possibility for a systematic yearly increase or decrease in the heat carrier temperature.

An example of the operating temperatures of a BHE field in which with more heat is extracted than input heat during the summer is shown in fig. 2. The calculations for that field accounts for 65 BHEs. The annual heat extraction is $534 \mathrm{MWh}$, and heat input is only $210 \mathrm{MWh}$. So an annual energy deficit of $324 \mathrm{MWh}$ exists, which accounts for the systematic decrease in the temperature of the heat carrier. 
Figure 2. Variability of maximum and minimum heat carrier temperatures for a BHE field with 50 wells during 20 years of operation (Sliwa 2012); 1 - maximum temperature during cooling mode (heat injected into rockmass), 2 - minimum temperature during heating mode (heat extracted from rockmass).

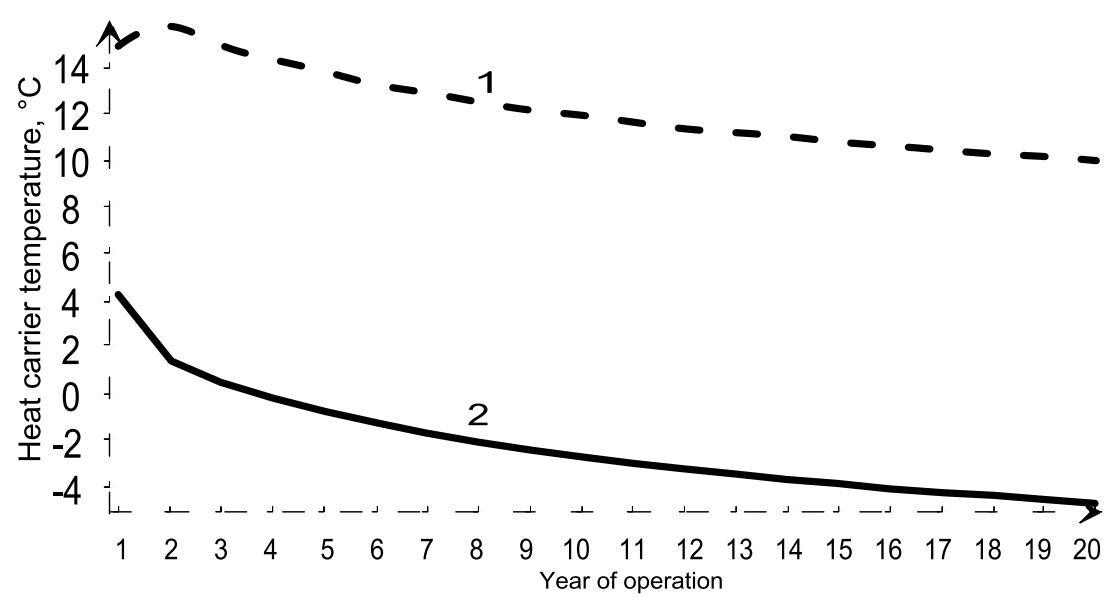

The variability of the maximum and minimum temperatures during 25 years of operation for a BHE field with 50 wells is shown in fig. 3. The system serves a poultry hatchery. Only $585 \mathrm{MWh}$ of heat is extracted from rock mass, while $830 \mathrm{MWh}$ is injected. The ground temperatures thus increase every year. The calculations for two example BHE fields have been made with EED3.16 software (Blomberg et al. 2008). Figure 4 shows the behavior of the temperature of the heat carrier when approximately balancing the amount of heat produced and input to the rock mass.

Figure 3. Variation of maximum and minimum temperatures of heat carrier with load time for 25 years of system operation (Sliwa 2012); 1 - maximum temperature during cooling mode (heat injected into rockmass), 2 - minimum temperature during heating mode (heat extracted from rockmass).

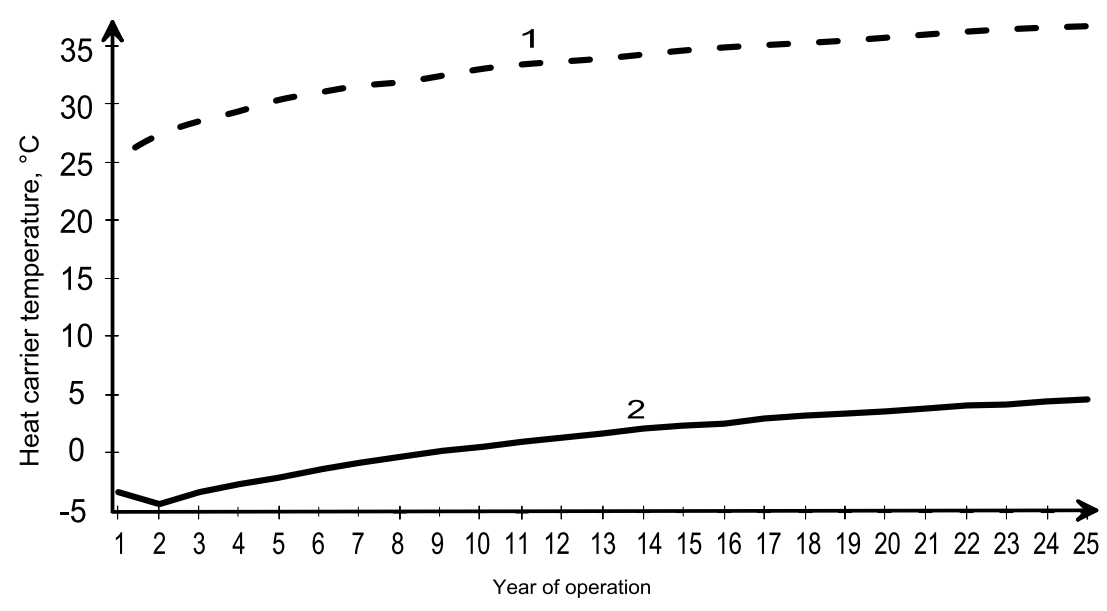

Figure 4. Minimum and maximum temperatures of heat carrier for operation of a nearbalanced BHE field (Sliwa 2012); 1 - maximum temperature during cooling mode (heat injected into rockmass), 2 - minimum temperature during heating mode (heat extracted from rockmass). 


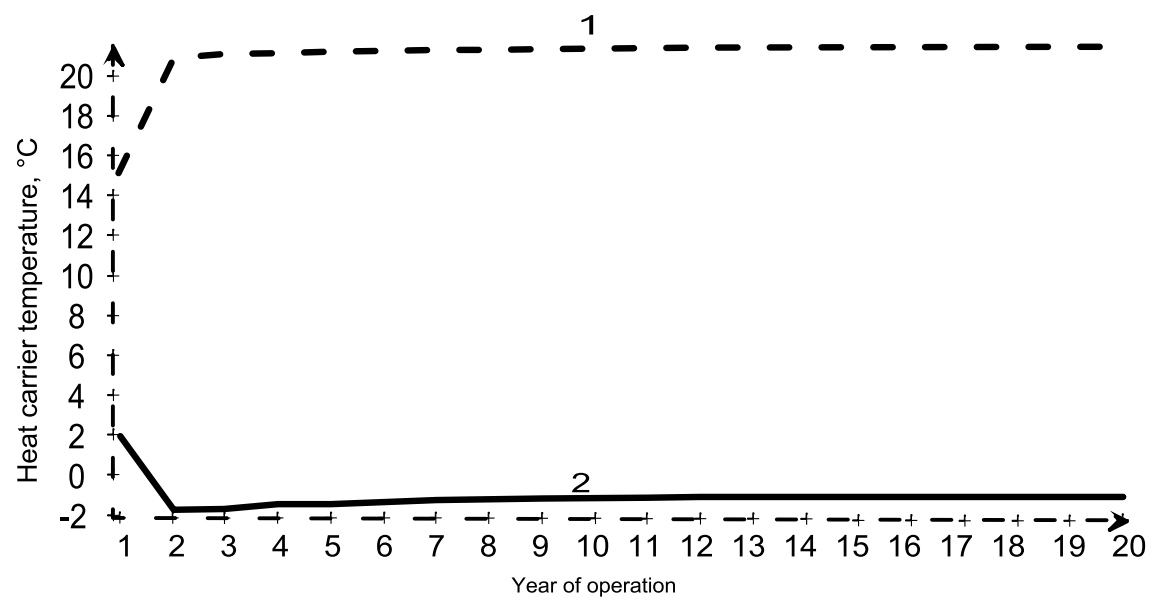

\section{Geoenergetics Laboratory}

At the end of 1990's the idea of converting existing, old boreholes to borehole heat exchangers (BHEs) was proposed at the Faculty of Drilling, Oil and Gas, AGH University of Science and Technology, Poland. After the research of Sliwa (2002), work began on building a BHE research facility in the area of university.

The Laboratory of Geoenergetics was inaugurated in 2007, when the first commercial Thermal Response Test (TRT) was performed in Poland (Gonet and Sliwa 2008). The first equipment of the laboratory was a TRT set. With funds from a 2008 research grant, the drilling of borehole heat exchangers began at AGH-UST. The Laboratory is based on five borehole heat exchangers of various designs. Also the types of grout and additive (Stryczek et al. 2013) influence the properties of cement. Research on the dependence of energy efficiency with construction and technology is important, and was therefore the first research task. The construction of the BHEs is described in table 1.

Table 1. Detailed parameters of BHEs of Laboratory of Geoenergetics (Gonet et al. 2011).

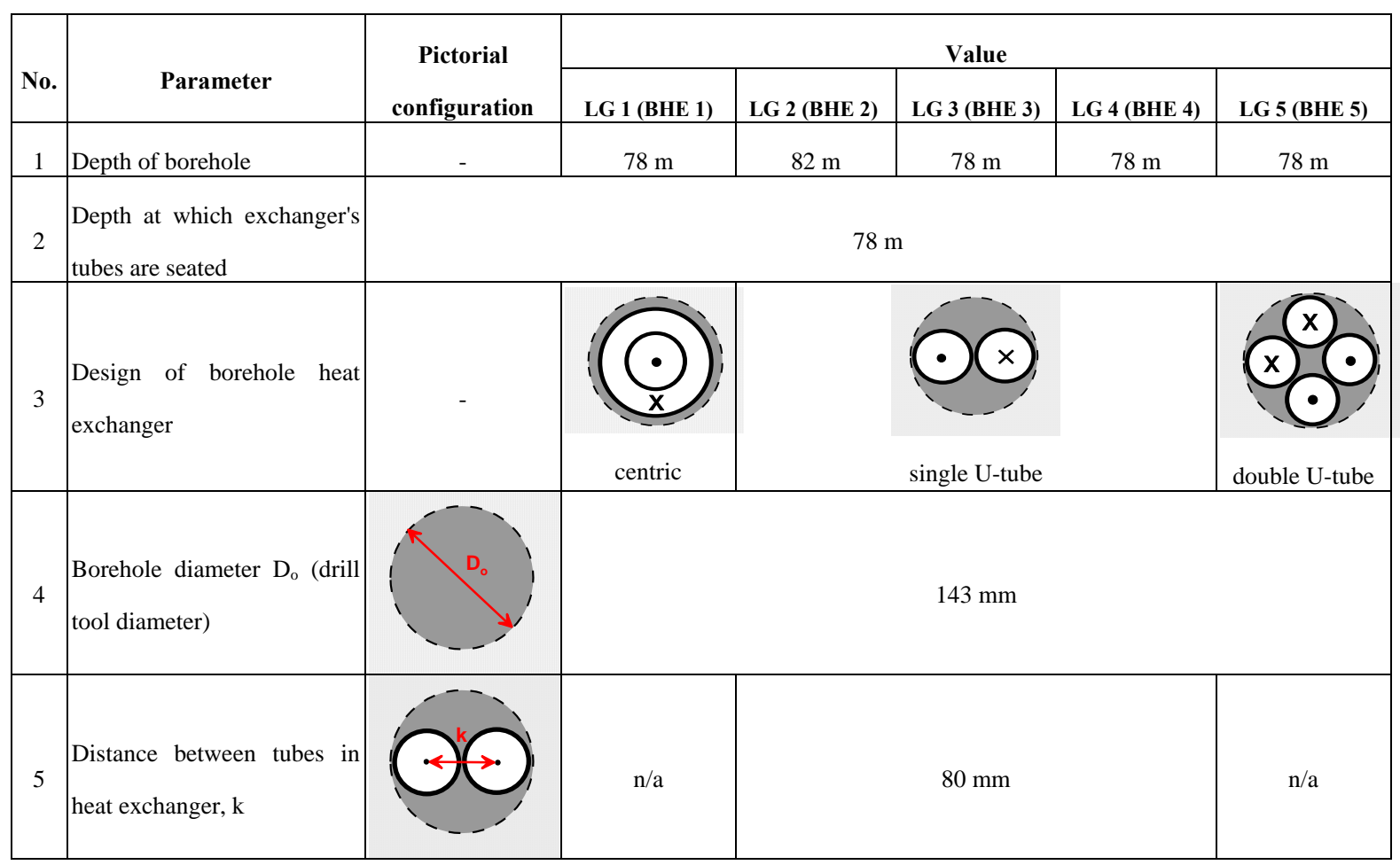




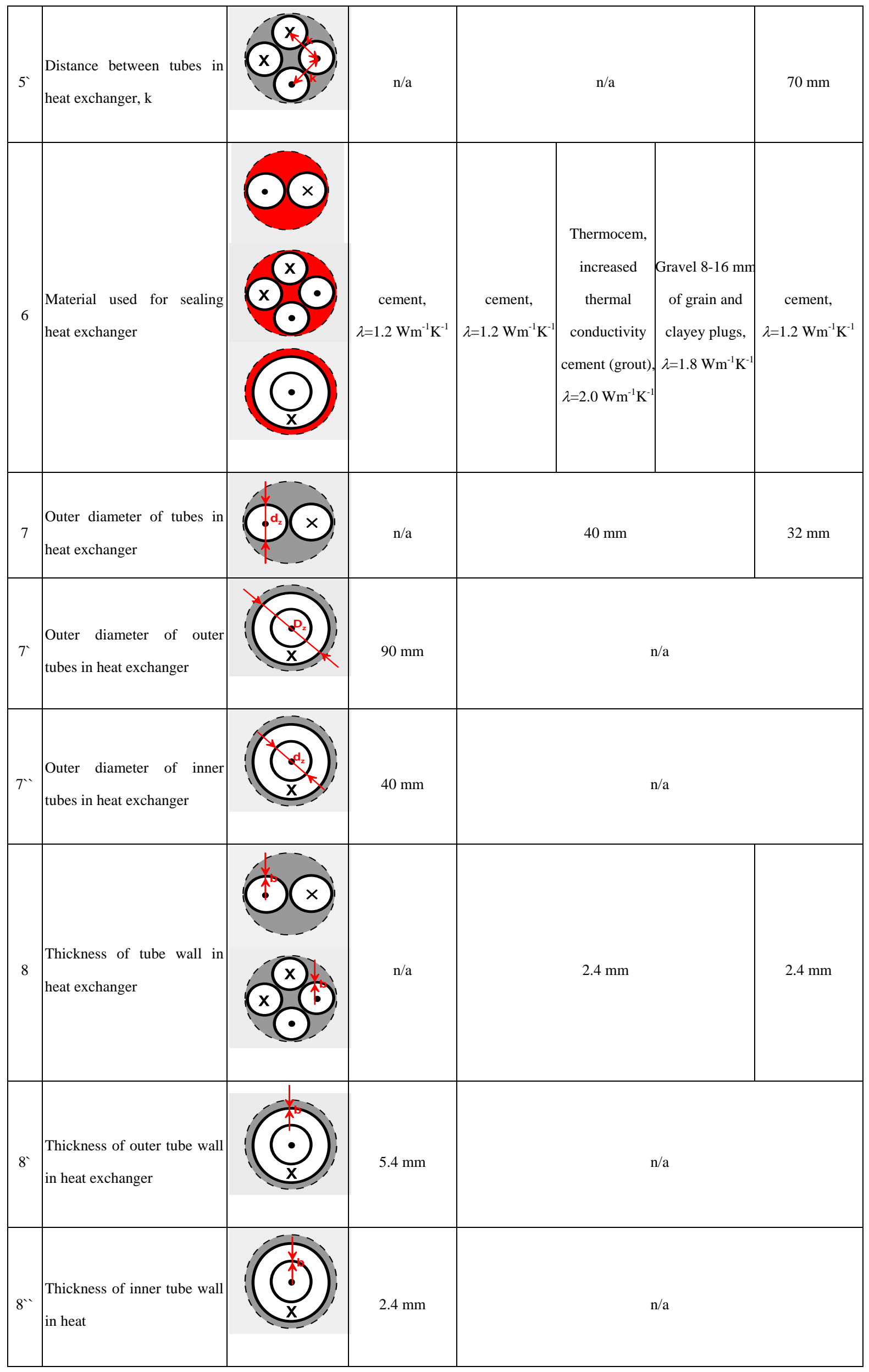




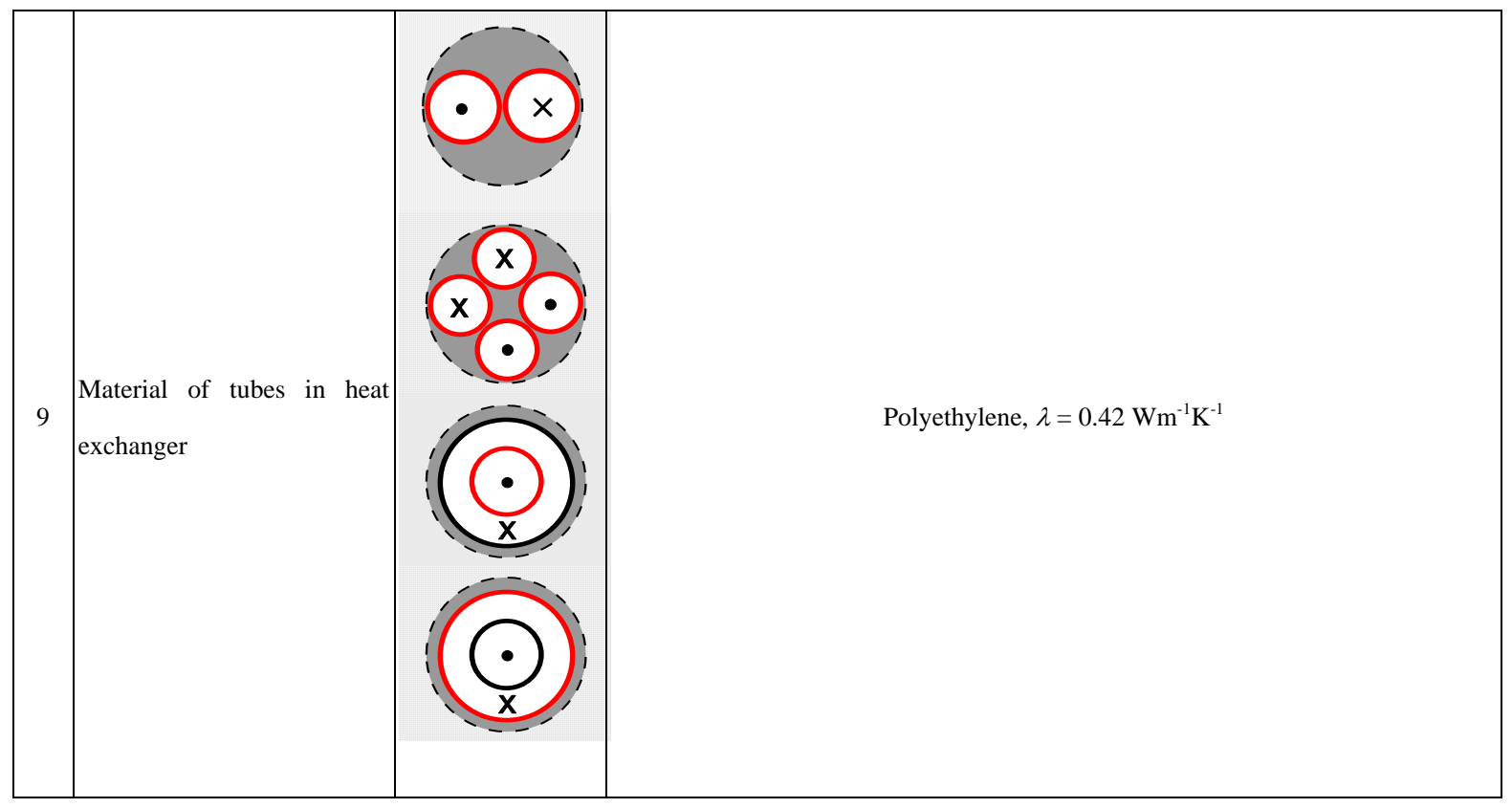

The lithological-stratigraphic profile under the Lab is presented in table 2 . The thermal conductivity of rocks and the volumetric specific heat are included. At a depth of 3-4 m, a good permeability layer begins. Its bottom is at a depth of $15 \mathrm{~m}$. In this layer underground water flows (fig. 5).

Table 2. Lithological and stratigraphic profile of BHE 2 (AGH LG-2 well) with thermal parameters of rocks (Gonet et al. 2011).

\begin{tabular}{|c|c|c|c|c|c|c|c|}
\hline No. & $\begin{array}{c}\text { Top, } \\
\text { m }\end{array}$ & $\begin{array}{c}\text { Bottom, } \\
\mathrm{m}\end{array}$ & $\begin{array}{c}\text { Thickness, } \\
\text { m }\end{array}$ & Lithology & Stratigraphy & $\begin{array}{c}\text { Thermal } \\
\text { conductivity, } \\
\lambda, \mathrm{W} \cdot \mathrm{m}^{-1} \mathrm{~K}^{-1}\end{array}$ & $\begin{array}{l}\text { Volumetric } \\
\text { specific heat, } \\
c_{v}, \mathrm{MJ} \cdot \mathrm{m}^{-3} \mathrm{~K}^{-1}\end{array}$ \\
\hline 1 & 0.0 & 2.2 & 2.2 & $\begin{array}{l}\text { Anthropogenic ground (dark } \\
\text { grey fill with debris) }\end{array}$ & \multirow{5}{*}{$\begin{array}{l}\text { Quaternary } \\
\text { (Pleistocene, } \\
\text { Holocene) }\end{array}$} & 1.600 & 2.000 \\
\hline 2 & 2.2 & 2.6 & 0.4 & Aggregate mud (grey ground) & & 1.600 & 2.200 \\
\hline 3 & 2.6 & 4.0 & 1.4 & $\begin{array}{l}\text { Fine, dusty and slightly } \\
\text { clayey sand }\end{array}$ & & 1.000 & 2.000 \\
\hline 4 & 4.0 & 6.0 & 2.0 & Fine sand & & 1.200 & 2.500 \\
\hline 5 & 6.0 & 15.0 & 9.0 & Sand and slag mix, slag & & 1.800 & 2.400 \\
\hline 6 & 15.0 & 30.0 & 15.0 & Grey clay & \multirow{3}{*}{$\begin{array}{l}\text { Tertiary } \\
\text { (Miocene) }\end{array}$} & 2.200 & 2.300 \\
\hline 7 & 30.0 & 78.0 & 48.0 & Gray clay slate & & 2.100 & 2.300 \\
\hline \multicolumn{5}{|c|}{ Weighted average } & & 2.039 & 2.309 \\
\hline
\end{tabular}


Figure 5. Location of borehole exchangers of Laboratory of Geoenergetics and direction of underground water flow.

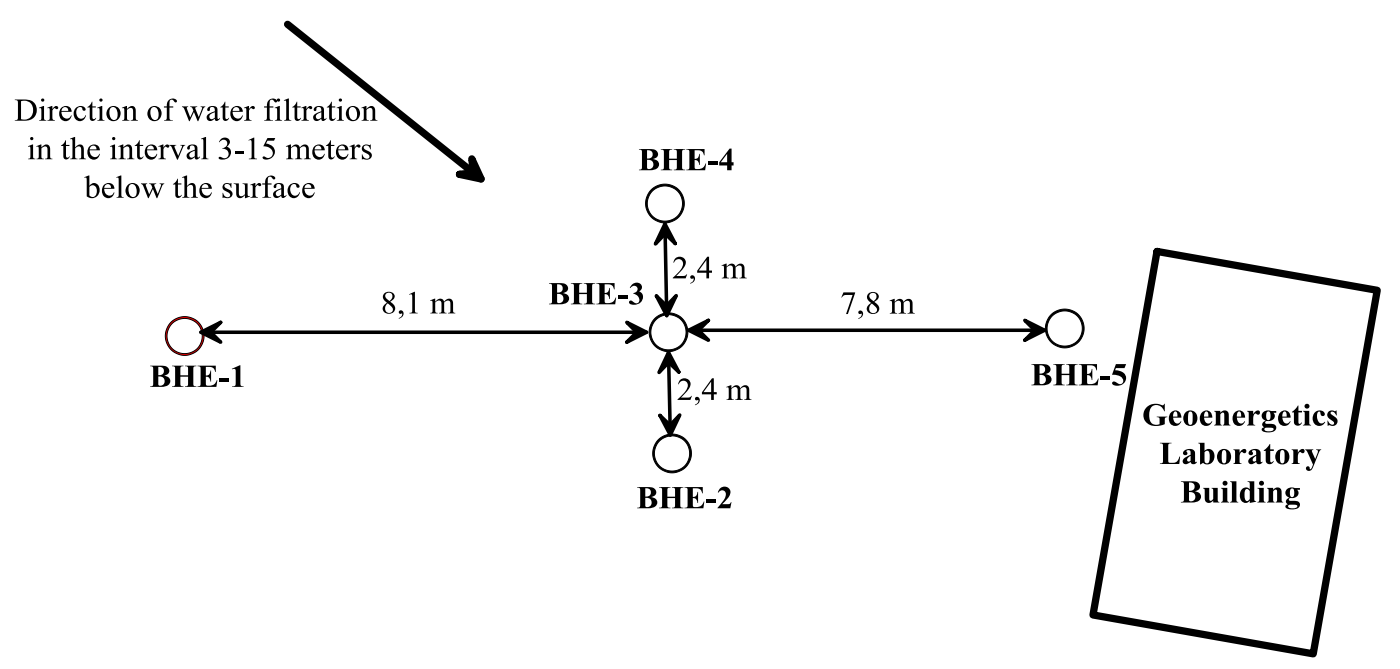

The Laboratory of Geoenergetics, after drilling and constructing the BHEs, was built on the surface. The installation is equipped with (Sliwa et al. 2015):

1. a heating-cooling system for the Faculty Auditorium, which has a seating capacity of 160 ,

2. solar collectors for regeneration of heat in the rock mass, with individual measurement sensors,

3. a system for snow melting of the parking lot in front of the Laboratory,

4. a fan for heating and cooling glycol using atmospheric air.

Heat streams in the Laboratory are listed in table 3 and shown in fig. 5, where arrows indicate the possible direction of heat flow. The installation has many possibilities for heat regeneration in the rock mass, or heat rejection (when necessary).

Table 3. Natural and artificial heat sources for regeneration of BHE field in Geoenergetics Laboratory.

\begin{tabular}{|c|l|l|}
\hline No. & $\begin{array}{l}\text { Natural heat sources for regeneration BHE } \\
\text { of field }\end{array}$ & $\begin{array}{c}\text { Artificial heat sources for regeneration BHE } \\
\text { of field }\end{array}$ \\
\hline 1 & Underground water flow & Heating-air-conditioning system of Auditorium \\
\hline 2 & Sun operation on surface (wind also) & Solar collectors \\
\hline 3 & $\begin{array}{l}\text { Heat transfer from the sides and bottom of the } \\
\text { BHE space }\end{array}$ & Snow melting installation \\
\hline 4 & $\begin{array}{l}\text { Heat transfer from the sides and bottom of the } \\
\text { BHE space }\end{array}$ & Fan (heater/cooler) \\
\hline
\end{tabular}

Figure 6. Schematic of directions of heat flows for various devices of the Geoenergetics Laboratory and by natural heat transfer. 


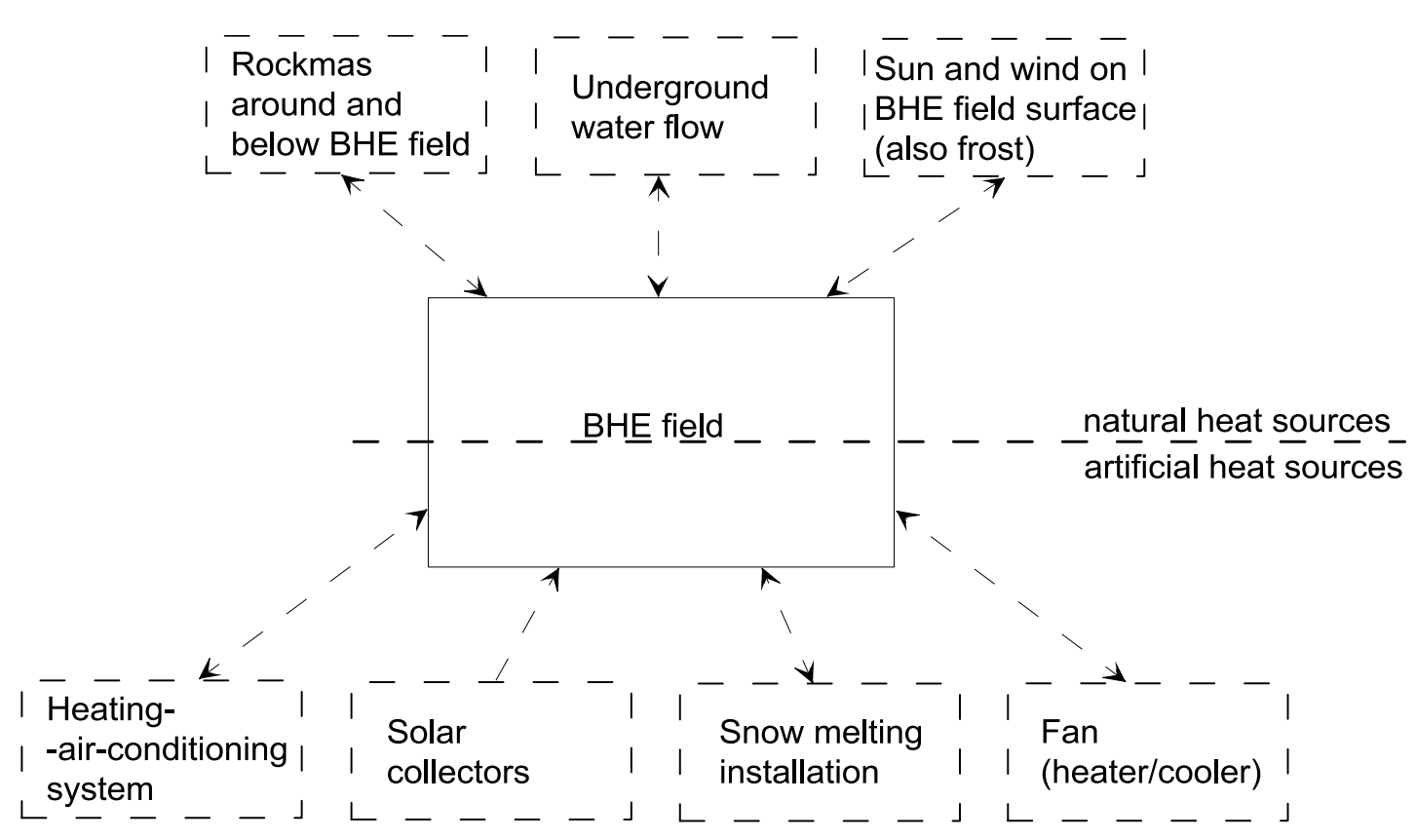

\section{Natural heat resources regeneration}

Solar radiation on the ground surface and warm ambient air/wind are two significant sources of heat for BHE fields. These sources are especially important when the depth of wells is not great. Temperatures profiles for the ground down to a $30 \mathrm{~m}$ depth are shown in fig. 6 for a borehole not using a BHE. This BHE well was made especially for temperature measurement. In a typical direct evaporation BHE field, the distance of this well from active BHEs (i.e., exploited ones) is about $5 \mathrm{~m}$ (Sliwa and Złotkowski 2014). Notable changes in temperature are observed to a depth of about $15 \mathrm{~m}$. No inflow of heat from exploited BHEs is observed in the field.

In deep BHEs, heat regeneration from solar radiation and ambient air is not as significant, and the importance declines as well depth increases. For BHEs in former oil wells (Sliwa et al. 2014) or other deep BHEs (Sapinska-Sliwa et al. 2015), including directional wells (Sliwa and Kotyza 2000; Knez 2014), it can be assumed for modeling that ground surface temperature is constant, at the average annual ambient air temperature.

Figure 7. Mean ground temperatures in a well not using an active BHE near Krakow (in the village of Pałecznica, $50 \mathrm{~km}$ northeast) broken down by month for the period October 2013 to September 2014 (Sliwa and Zlotkowski 2014). 


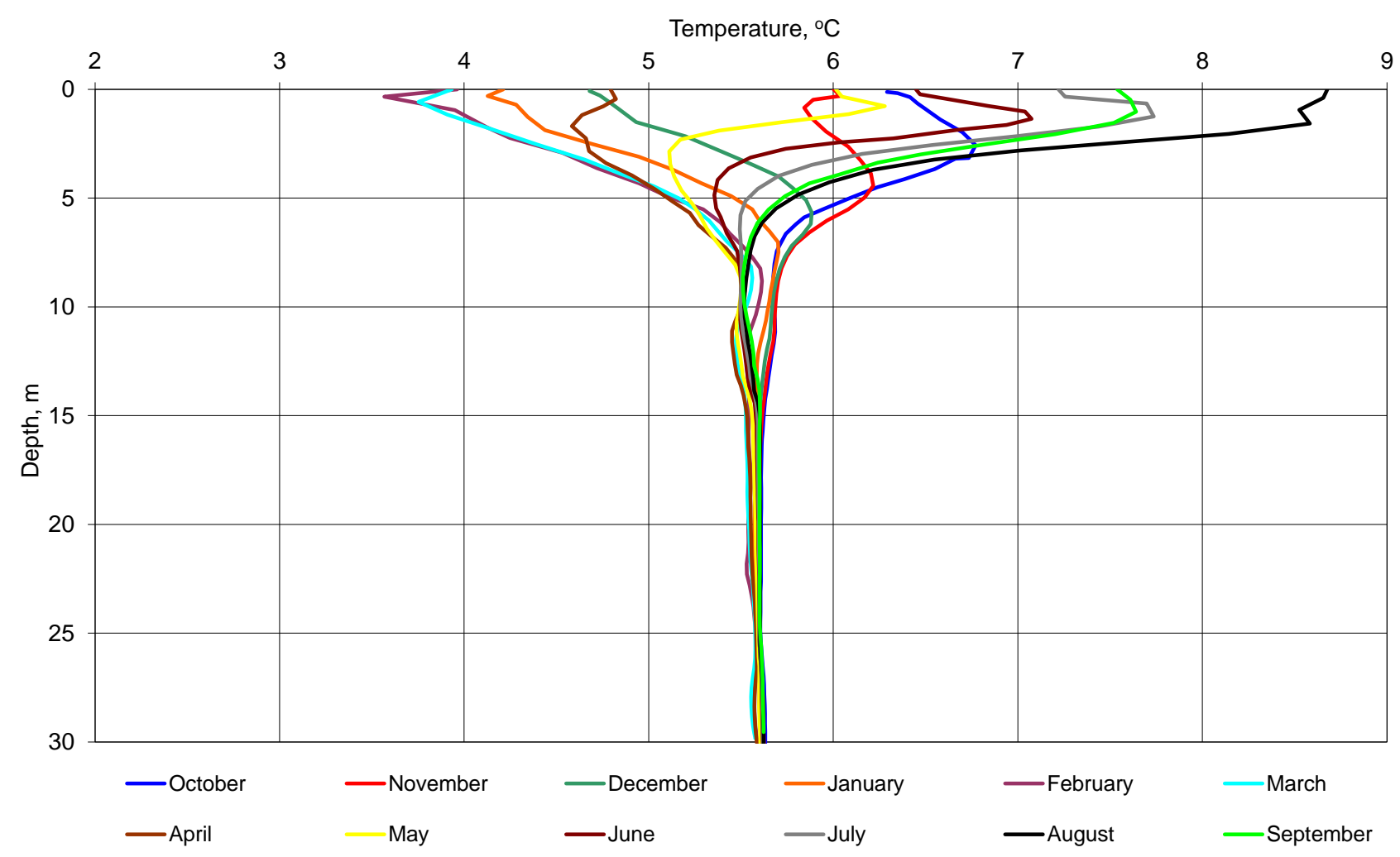

The second group of heat sources for resource regeneration is geothermic heat from around and under the BHE field. When a geothermal source heat pump (GSHP) system is the only regeneration heat source, heat conduction from rocks only may not be sufficient, and the temperature of the BHE field may drop every year, as shown in fig. 2. The renewability of heat in such BHEs fields is not complete (Cataldi 2001, Signorelli et al. 2004). After a few years of temperature drop, the temperature takes on a low value at which point heat from surrounding rocks can conduct adequately to the field. Then the temperature of the BHE field reaches a value where the extracted heat has the same value as heat conducted from surrounding rocks for regeneration.

The third group of natural heat sources for regeneration is convection. In the case where underground water flow is present, heat transfer can accompany the mass flow. In fig. 7 the results are shown of a numerical simulation of a deep BHE with a permeability layer (Sliwa and Gonet 2005). At depths of 300-400 m, the isotherm curves are clearly disturbed.

In fig. 8, the temperature distribution is shown around the five BHEs of the Geoenergetics Laboratory. In the interval 3-15 m deep is a moist layer with water flow (as shown in fig. 5). A crosssection at a depth of $9 \mathrm{~m}$ (inside the underground water layer) is shown in fig. 9 . The increased heat convection is visible according to the direction of flow of water. 
Figure 8. Isotherms (in ${ }^{\circ} \mathrm{C}$ ) for a cross-section through a deep BHE (Sliwa 2002).

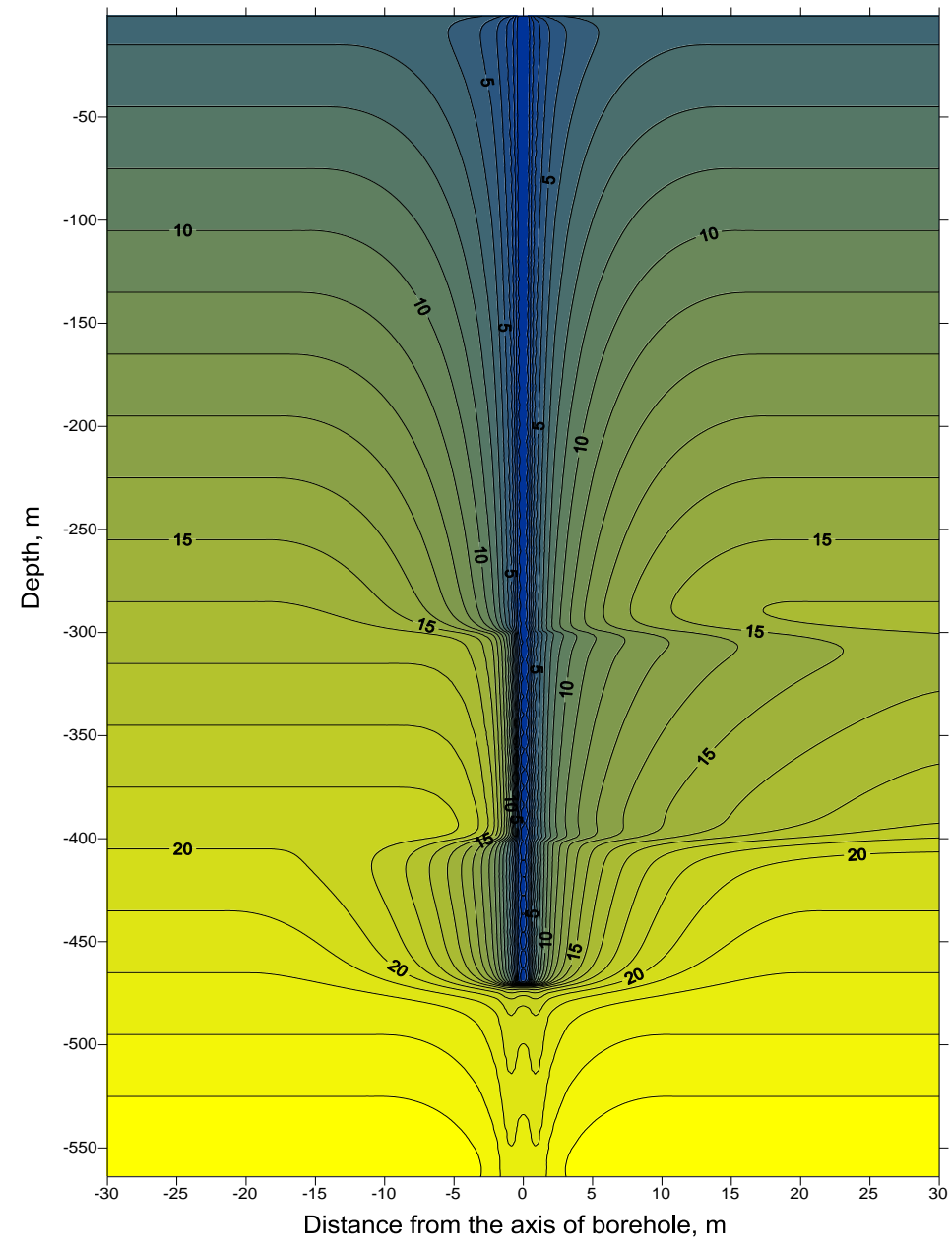

Figure 9. Vertical cross-section through BHEs of Laboratory of Geoenergetics (wells no. 1,3 and 5, as shown in fig. 5) showing isotherms (in ${ }^{\circ} \mathrm{C}$ ) from numerical simulation (Sliwa 2012). 


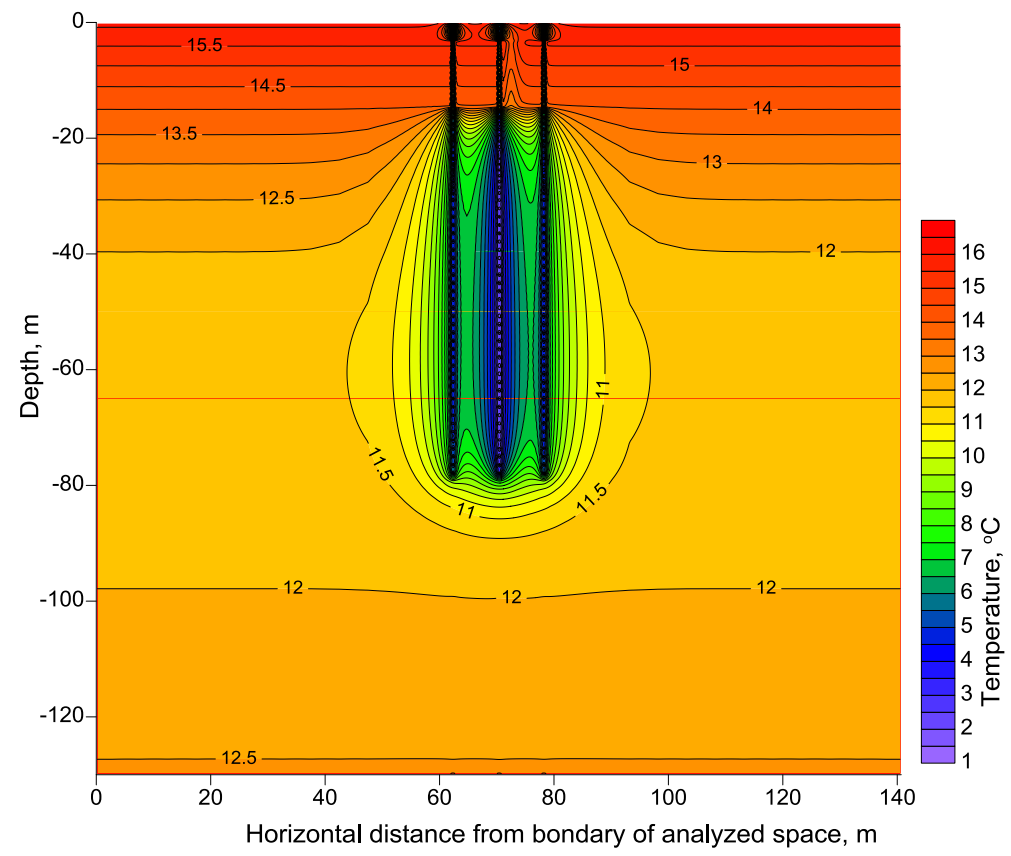

Figure 10. Horizontal cross-section at a level $9 \mathrm{~m}$ below the ground surface showing isotherms (in ${ }^{\circ} \mathrm{C}$ ) based on simulation for exploited BHEs at the Geoenergetics Laboratory (Sliwa 2012).

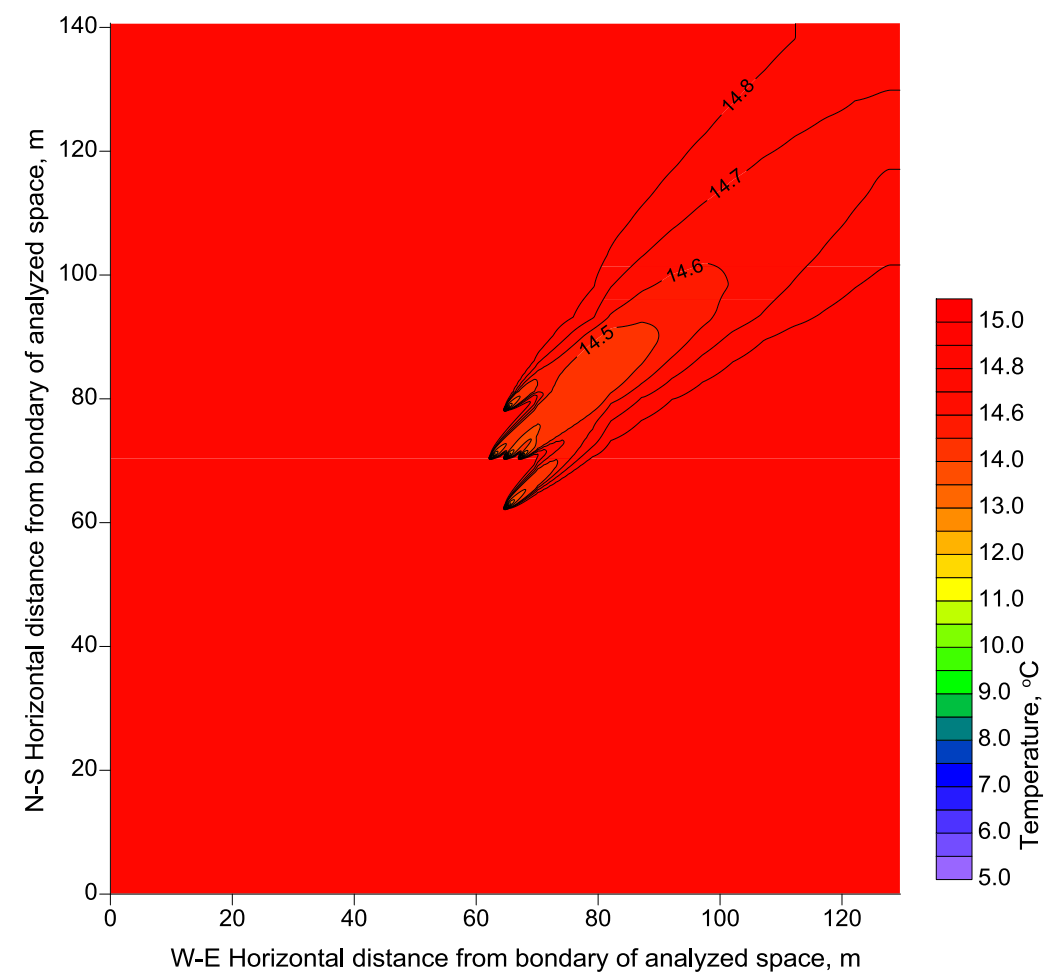

Natural ways of heat regeneration can result in full or only partial temperature regeneration. When full temperature renewability is not achieved due to supplemental heat resources, it is necessary to use artificial sources of heat.

\section{Artificial heat resources regeneration}

The only sources of heat existing in the Geoenergetics Laboratory are described here. In real projects, it is necessary to take into consideration all possible options. 


\subsection{Heating/air-conditioning system of the Auditorium}

BHEs fields typical work by heat injection into the surrounding rock mass. Hotels, office buildings, commercial facilities, university buildings, and private residences can use BHEs for heating and airconditioning. The simple payback time for investment costs of such installations can be lower than 10 years. Using heat pumps can avoid the need for separate heating and cooling equipment. Also operational costs of heating and cooling are often lower than traditional methods. In countries with temperate climates, the amount of energy from air-conditioning injected into rock mass in summer is usually lower than the heat extracted from ground in winter time.

\subsection{Solar collectors}

Five solar collectors have been investigated in terms of heat recovery performance. The best results regarding efficiency is achieved for a collector "heat pipe", while the lowest efficiency is observed for a stationary flat-plate collector. Much better efficiency is observed when the temperature of working fluid of the heat pipe, glycol, is low. In typical heating systems, for domestic hot water heating for example, the efficiency of solar collectors is about 60-70\%. In case of circulating the heat carrier from BHEs, at low temperatures, the efficiency can be higher than $80 \%$ (Sliwa 2012). In the Laboratory of Geoenergetics, the heating stream was also observed in the night. That occurred in summer, when the ambient air temperature of was high. About $0.5 \mathrm{~kW}$ heating power can be attained with five solar collectors, using low-temperature glycol to transfer heat into rock mass (Sliwa 2012).

\subsection{Snow melting installation}

In laboratory testing facility, a heating rate of over $33 \mathrm{~kW}$ was possible. Over a minimum duration of 32 minutes, it was possible to attain 58.5 MJ of heat transfer from the parking area, which was 1880 $\mathrm{m}^{2}$ (Śliwa and Poniedziałek 2014). The system working fluid is a glycol solution. The time to raise the temperature of $1.50 \mathrm{~m}^{3}$ glycol from 0 to $10{ }^{\circ} \mathrm{C}$ was observed.

The snow melting installation works like a solar collector in summer. It receives heat from solar radiation and warm air on the surface. The unit heating rate observed is $17.5 \mathrm{~W} / \mathrm{m}^{2}$ when the maximum solar energy $\left(900-1000 \mathrm{~W} / \mathrm{m}^{2}\right)$ is received from collectors. The unit heat extracted from the parking area is $31.1 \mathrm{~kJ} / \mathrm{m}^{2}$ over a period of $32 \mathrm{~min}$.

Research was also undertaken by partially shading the parking area. It is necessary to prepare long term observations (at least one year) to determine seasonal effects and outputs.

The installation for snow melting can be used in summer not only for heat extraction, but also for cooling the surface of road, to protect against ruts (Heliasz and Ostaficzuk 2002).

\subsection{Fan (heater/cooler)}

In the Geoenergetics Laboratory, research was undertaken on heating $1.0 \mathrm{~m}^{3}$ of glycol solution. For the snow melting installation, the initial temperature of the heat carrier was $0{ }^{\circ} \mathrm{C}$, and the final temperature was $10{ }^{\circ} \mathrm{C}$. Poniedziałek and Sliwa (2013) demonstrate that it is possible to obtain examples of research. Various air temperatures with time of heating have been measured. For the average air temperature $\left(18.1^{\circ} \mathrm{C}\right)$, the average heating time was $233 \mathrm{~min}$, leading to an average heating power of $4.18 \mathrm{~kW}$. 
Using the fan is probably the most inexpensive way for heating, considering investments and operational costs. The fan can heat the working medium when the air temperature is higher than the temperature of the glycol solution, also in warmer winter days.

\section{Conclusions}

1. Natural ways of heat regeneration can permit full or partial temperature restororation. For supplemented heat resources, when natural full renewability is not possible but necessary (or advantageous), artificial sources of heat can be used.

2. In real projects, it is necessary to take into consideration all possible options for obtaining heat. Sometimes it is possible to obtain a low-temperature heat flux from other sources, such as waste heat.

3. Nowadays designers should analyze all energetic aspects of buildings and other structures as well as the neighborhood of designed projects.

4. BHE fields can be effectively used for energy storage. This is particularly important for renewable energy sources, which are often characterized by intermittency (like wind energy for example). Energy storage also enables greater use of distributed energy sources.

5. Natural heat regeneration options for BHEs storages are sun, wind, surrounding rocks and underground water. Artificial options that can be used include solar heat using, for example, air-conditioning installations, solar collectors, fans and snow melting installations working in reverse mode. It is also possible to use waste heat from industry.

\section{Acknowledgments}

The paper was founded in Statutory Research carried out at the Drilling, Oil and Gas Faculty, AGH University of Science and Technology, funded by the Polish Ministry of Science and Higher Education. The authors thank Agnieszka Pycia and Tomasz Nowosiad from the Student Scientific Association GEOWIERT AGH-UST DOGF for help in preparing of some pictures.

\section{Conflict of Interest}

The authors declare no conflict of interest.

\section{References and Notes}

1. Blomberg T.; Claesson J.; Eskilson P.; Hellström G.; Sanner B. Earth Energy Designer (EED 3.16), Software Within Building Physics And Ground Heat Storage, Manual, 2008, p. 60 (available at: http://www.buildingphysics.com/manuals/EED3.pdf).

2. Cataldi R., Sustainability and renewability of geothermal energy, Proceedings: International Scientific Conference on Geothermal Energy in Underground Mines, Ustron, Poland; 21-23 November 2001, (available at: http://www.geothermalenergy.org/pdf/IGAstandard/Poland/2001/a4.pdf?)

3. Gonet A.; Sliwa T. Thermal Response Test on The Example of Borehole Heat Exchangers in Ecological Park Of Education and Amusement "OSSA", Transport \& Logistics 2008, 6, 42-47. 
4. Gonet A.; Sliwa T.; Stryczek S.; Sapinska-Sliwa A.; Jaszczur M.; Pająk L.; Złotkowski A. Metodyka identyfikacji potencjału cieplnego górotworu wraz z technologia wykonywania i eksploatacji otworowych wymienników ciepła (Methodology for the Identification of Potential Heat of The Rock Mass Along with Technology Implementation and Operation of the Borehole Heat Exchangers), ed. Andrzej Gonet, Wydawnictwa AGH: Krakow, Poland, 2011.

5. Heliasz Z.; Ostaficzuk S. Możliwości i sposoby wykorzystania w Polsce ciepła odpadowego i energii geotermalnej do odśnieżania i odladzania - koncepcje i problemy (Possibilities and ways to use in Poland the waste heat and geothermal energy for snow melting and de-icing concepts and problems), Prace Wydziatu Nauk o Ziemi Uniwersytetu Ślaskiego 2002, 17, 243 256.

6. Knez D. Stress State Analysis in Aspect of Wellbore Drilling Direction, Archives of Mining Sciences 2014, 59/1, 69-74.

7. Poniedziałek M.; Sliwa T. The Use of a Heater and Borehole Heat Exchangers for Regeneration of Heat Resources in The Rock Mass on the Example of the Geoenergetics Laboratory, AGH Drilling, Oil, Gas 2013, 30/2, 353-359.

8. Sapinska-Sliwa A.; Jaszczur M.; Gonet A.; Sliwa T. Experimental studies of the influence of the working fluid type on the efficiency of borehole heat exchangers, Book of abstracts XXI Fluid Mechanics Conference, AGH University of Science and Technology, Polish Academy of Science, Krakow, Poland, 15-18 June 2014.

9. Sapinska-Sliwa A.; Rosen M.A.; Gonet A.; Sliwa T. Deep Borehole Heat Exchangers: a Conceptual Review, Proceedings World Geothermal Congress 2015, Melbourne, Australia, 1925 April 2015, pp. 1-11 (accepted).

10. Signorelli S., Kohl T., Rybach L. Sustainability of Production from Borehole Heat Exchanger Fields, Proceedings, Twenty-Ninth Workshop on Geothermal Reservoir Engineering, Stanford University, Stanford, California, January 26-28, 2004, SGP-TR-175, (available at: http://www.geothermal-energy.org/pdf/IGAstandard/SGW/2004/Signorelli.pdf?)

11. Sliwa T. Badania podziemnego magazynowania ciepła za pomoca kolektorów słonecznych $i$ wymienników otworowych (Research on underground thermal energy storage by use solar collectors and borehole heat exchangers), Wydawnictwa AGH: Kraków, Poland, 2012; pp. 272.

12. Sliwa T. Techniczno-ekonomiczne problemy adaptacji wykorzystanych odwiertów na otworowe wymienniki ciepła (Technical and Economic Problems of Adaptation of Used Wells into Borehole Heat Exchangers), Ph.D. thesis, AGH University of Science and Technology in Krakow, Krakow, 2002.

13. Sliwa T.; Gonet A. Theoretical model of borehole heat exchanger, Journal of Energy Resources Technology 2005, 127/2, 142-148.

14. Sliwa T.; Kotyza J. Dobór optymalnego otworowego wymiennika ciepła w otworze Jachówka $2 \mathrm{~K}$ do głębokości $2870 \mathrm{~m}$ (Selection of optimal construction of borehole heat exchangers based on Jachówka 2K well to a depth $2870 \mathrm{~m}$ ), In Metodyka i technologia uzyskiwania użytecznej energii geotermicznej z pojedynczego otworu wiertniczego (Methodology and technology of obtaining usable energy from a single geothermal borehole), ed. J. Sokołowski, Polgeotermia and Instytut Gospodarki Surowcami Mineralnymi i Energią PAN Pracownia Geosynoptyki i Geotermii: Kraków, Poland, 2000, pp. 251-284. 
15. Sliwa T.; Poniedziałek M. Wykorzystanie instalacji ośnieżania powierzchni parkingu do regeneracji zasobów w podziemnym magazynie ciepła za pomocą wymienników otworowych (Use of the parking area snow melting installation to regenerate the energy resources in the underground heat storage using borehole heat exchangers), article in prep. 2014, pp. 1-16.

16. Sliwa T.; Rosen M.A.; Jezuit Z. Use of Oil Boreholes in the Carpathians in Geoenergetics Systems Historical and Conceptual Raview, Research Journal of Environmental Sciences 2014, 8/5, 231-242.

17. Sliwa T.; Wiśniowski R.; Gonet A.; Sapinska-Sliwa A.; Szlapa B. Research and Teaching Capacities of the Geoenergetics Laboratory at Drilling, Oil and Gas Faculty AGH University of Science and Technology in Kraków (Poland), Proceedings World Geothermal Congress 2015, Melbourne, Australia, 19-25 April 2015, pp. 1-14 (accepted).

18. Śliwa T.; Złotkowski A. Pomiary temperatury podziemnego magazynu ciepła w Pałecznicy, Proceedings: Seminarium pt. „Efektywność energetyczna w gminach na przykładzie Pałecznicy” (Seminar on „Energy efficiency in communes on example of the village Pałecznica"), 2014, pp. 1-9.

19. Stryczek S.; Wiśniowski R.; Gonet A.; Złotkowski A.; Ziaja J. Influence of polycarboxylate superplasticizers on rheological properties of cement slurries used in drilling technologies (Wpływ superplastyfikatorów z grupy polikarboksylanów na właściwości reologiczne zaczynów cementowych stosowanych w technologiach wiertniczych), Archives of Mining Sciences 2013, 58/3, 719-728.

(C) 2014 by the authors; licensee MDPI, Basel, Switzerland. This article is an open access article distributed under the terms and conditions of the Creative Commons Attribution license. 